\title{
Descaminhos e intraduzibilidade: da lírica e da verdade
}

\author{
Waywardness and untranslatability: lyrical and truth
}

\author{
Divino José Pinto \\ PUC-Goiás \\ djlages@hotmail.com
}

RESUMO: Este trabalho apresenta como preocupação central uma forma didática de lidar com a lírica, que parte de seus aspectos estruturais, passando pela sua conformação de sua significância, para finalmente, se chegar à sua função pragmático-poética, aliada aos pressupostos de teóricos que tratam a tradução, principalmente na sua dimensão intralingual quando a leitura de poesia se torna um exercício de tradução daquilo que é intraduzível. Utilizando como texto exemplar o poema "Verdade" de Carlos Drummond de Andrade, pretende-se demonstrar aqui a maneira com que esse processo se efetiva na poesia propriamente dita, ressaltando também a tendência da arte modernista de misturar gêneros para obter resultados inusitados e, assim, estabelecer uma nova modalidade de comunicação, calcada, consciente e propositalmente, no insólito.

Palavras-chave: Lírica. Intraduzibilidade. Verdade. Signo. Pragmática.

\begin{abstract}
This work shows as its central worry a didactic way of dealing with the poetry starting from their structural features, passing truth its significance conformation, to finally reach its function poetic pragmatic, coupled with the theoretical assumptions that address translation, especially in its intralingual form when reading poetry becomes a translation exercise of what is untranslatable. Using as example text the poem "Verdade", by Carlos Drummond de Andrade, intended to demonstrate here, the way by the which this process is realized in the poetry itself, also emphasizing the tendency in Modern Art of mixing gender in order to get unusual results and so establish a new mode of communication, based, consciously and deliberately, in unusual.
\end{abstract}

Keywords: Poetry. Untranslatability. Truth. Sign. Pragmatic.

\section{Introdução}

À guisa de advertência, fazem-se necessárias algumas palavras que dizem respeito ao método utilizado no presente estudo. Trata-se 
da aplicação, no poema "Verdade", de Carlos Drummond de Andrade, de uma visão crítica que adota como fio condutor os postulados do esteta russo S. Zótkiewski, contidos em seu manual denominado Crítica, traduzido em Portugal por Maria Évora Águas, associado a pressupostos da tradução, e, mais precisamente, da intraduzibilidade do signo poético, mesmo no universo intralingual. Tomaremos por base estes princípios críticos, promovendo breves diálogos com outros estudiosos da arte lírica que também privilegiem, como objeto de seus estudos literários, a problemática do texto, da autoria, da comunicação social, do leitor e do código; elementos centrais da análise semiótica, considerando o seu processo construtivo no plano sintático-estrutural, passando pelo semântico para chegar ao pragmático; quando, de fato, um texto poético se confirma como parte de um sistema ou, como aponta Even-Zohar (1981), de um polissistema, uma vez que, para esse autor, todo sistema cultural/artístico é permeado de pequenos sistemas de cujo embate emergem a tradição, a permanência e, principalmente, a evolução desse polissistema.

Dessa forma, trataremos inicialmente dos aspectos estruturais inerentes ao vocabulário, da sua polissemia, intraduzível por completo, atentando para o material sonoro-construtivo que compõe o significante, para, depois, observarmos os aspectos semânticos, com ênfase na capacidade e na proposta enunciativas: o esvaziamento semiológico como recurso de expansão da imagem poética, as fronteiras/desfronteiras de sentido no ambiente intralingual e, por último, nossa atenção repousará sobre a pragmática observável no texto drummondiano em pauta, numa visão, ainda que breve, do conjunto. Destacaremos o fazer poético como matéria de sua própria linguagem, como também, as

Revista Texto Poético | ISSN: 1808-5385 | Vol. 18 (10 sem-2015) - p. 257 
especificidades do discurso poético, o signo complexo - utilizando o termo verdade como signo exemplar -, além de outras motivações como a intencionalidade poética, a marca do intraduzível em poesia, na visão intra ou interlinguística, e de outras operações de sua linguagem que nos envia para além das dicotomias reducionistas, sugerindo leituras mais profundas de um produto artístico pautado, cuidadosamente, pelo movimento dialético.

\section{Falando de poesia}

A poesia, tida e havida como a forma mais primitiva do discurso literário, tem como fator primordial o ritmo. No entanto, o ritmo não é exclusividade do "sistema poético". As formas narrativas mais conhecidas também têm seu ritmo e, muitas vezes, encontramos em trechos consideráveis de um romance, de uma novela ou de uma narrativa curta (conto, crônica e outros), uma estrutura sintática completamente adversa daquela que se pode ver na fala cotidiana absolutamente despretensiosa, desprovida de qualquer efeito de estilo. São estes vestígios, perceptíveis no material linguístico do discurso literário que nos permitem compreender que, embora o poema seja, groso modo, uma forma fixa de escrita em versos, a poesia - discurso poético - vai transcender, nos múltiplos sentidos, tal procedimento estrutural: ela estará em qualquer parte do discurso que conjugue som e imagem, suscitando sentidos. Estes elementos, por sua vez, são sempre intangíveis, são escorregadios e nunca se deixam apanhar por inteiro.

O crítico russo Iuri Lotman, em A estrutura do texto artístico (LOTMAN, 1978, p. 175), afirma que "O texto artístico não pertence a um único sistema, ou a qualquer tendência". 
A propósito de tal assertiva, temos a salientar que toda noção cristalizada como verdade absoluta no que concerne à pureza de um gênero literário, ou de uma leitura de um texto, mormente o lírico, é suscetível de questionamento, uma vez que a instância maior da poesia se materializa no indefinível, no impensável. Assim sendo, somos reenviados sempre à questão básica relativa à pureza ou não dos gêneros literários e à eterna e frutífera celeuma do que seja a tradução, seus limites/deslimites. Acreditamos então que a leitura de texto literário com propósitos estéticos e científicos, destacando a leitura do texto lírico, seja um procedimento tradutório, confirmado pelo fato de que pessoas em diferentes situações culturais, sociais, com diferentes níveis de escolaridade, acessam essas formas de linguagens de modos diferentes e, nesse momento, o leitor crítico que lida com suporte teórico e terminologia apropriados serve de intérprete, tradutor dessas formas textuais que exigem, além de clarividência científica, uma visão de mundo que dialoga com a arte acurada.

A cultura estética reivindica em cada época um formato que atenda aos seus critérios e exigências. É certo, porém, que o vocábulo poesia nunca deixou de ser tomado semanticamente como centro irradiador de energias, de significações; independentemente da roupagem que possua ou da sociedade e da cultura das quais emerge. Uma narrativa também tem seus fundamentos preservados em qualquer período, assim como o drama se faça sempre reconhecer por alguns de seus traços permanentes. Todavia, a consciência estética é um processo que vai se amalgamando pela experiência herdada na observação; é exercício que obviamente demanda muito tempo e, mesmo assim, jamais alcança a plenitude.

Certa vez, o aclamado poeta Carlos Drummond de Andrade, quando lançava sua coletânea intitulada Poesia Completa, ao autografar um exemplar dedicado a um 
amigo, o também escritor goiano Gabriel Nascente, assim se manifestou: "Poesia completa? Falta uma palavra surgida do puro silêncio, alta expressão de toda vida" (NASCENTE. In: ANDRADE, 1992, p. 17).

Se Drummond nos adverte que não existe a poesia completa, deduz-se a partir daí que também não existe nenhum gênero completo, tanto no sentido de estar acabado quanto no sentido de conter a verdade como "... alta expressão de toda vida".

Esta "expressão de toda vida", aliás, ao que pudemos notar, é bastante recorrente em Drummond. Ela nos remete ao problema da incompletude da palavra e revela a angústia do poeta ao perceber uma lacuna impreenchível, um espaço de ausência e silêncio; espaço inatingível da verdade, em todos os sentidos.

A expressão "meias verdades", reiteradamente proferida na linguagem comum, muitas vezes, com intenções pejorativas, parece calhar bem quando o assunto é Literatura.

\section{2 . Um poema exemplar}

Drummond, em seu poema, com o provocante título "Verdade", indaga poeticamente, acerca desse jogo, cuja regra fundamental é a ausência de regra fixa:

\section{VERDADE}

A porta da verdade estava aberta

mas só deixava passar

meia pessoa de cada vez. 
Assim não era possivel atingir toda verdade

porque a meia pessoa que entrava

só trazia o perfil da meia verdade.

E sua segunda metade

voltava igualmente com meio perfil.

E os meios perfis não coincidiam.

Arrebentaram a porta. Derrubaram a porta.

Chegaram ao lugar luminoso

onde a verdade esplendia seus focos.

Era dividida em metades

diferentes uma da outra.

Chegou-se a discutir qual a metade mais bela.

Nenhuma das duas era totalmente bela.

E carecia optar. Cada um optou conforme

seu capricho, sua ilusão, sua miopia.

(ANDRADE, 1992, p. 1005)

O poema em questão se assenta em base rítmica irregular, à semelhança do discurso prosaico, fato comum em se tratando de um texto modernista. A tal expediente, contudo, subjazem marcas rítmicas próprias da tradição lírica, sinais indeléveis que remetem a procedimentos estéticos de base da poesia. E, assim, este poema vaise constituindo em vigoroso exemplo de mobilidade dialética, ao conjugar tradição e ruptura.

\section{1 A dança do signo e da forma}

A alternância de ritmos entre os blocos silábicos em binários, ternários e quaternários, presente logo no primeiro conjunto de três versos, faz aflorar, por um lado, o recurso canônico da poesia clássica, posto que cada uma dessas formas aparece em uma sequência vertical. Por outro lado, essa alternância disposta num 
mesmo verso, se observada linearmente, foge à lógica canônica da poesia, propondo, na mesma medida, um poema híbrido que se faz tanto da regularidade quanto da irregularidade rítmicas. Tal irregularidade remete ao que já anunciamos neste trabalho anteriormente, quanto à intraduzibilidade, posto ser esta movimentação que mobiliza/imobiliza os sentidos e requer não uma interpretação peremptória, mas um constante exercício de tradução do possível.

Percebemos, então, não se tratar apenas de um poema de forma livre, mas sim, de um poema que, de certo modo, questiona em sua realização a própria noção de liberdade poética. Tal uso da liberdade na manipulação do discurso coloca em suspensão conceitos básicos como o de licença poética, metrificação, ritmo e outros procedimentos internos do texto.

Depreendem destes fatos, inerentes à composição, índices de uma tensão rítmica, considerando que, sobre os vocábulos cruciais deste primeiro conjunto de versos, como o substantivo verdade e o verbo de ação passar, incidem o acento quaternário; tornando o ritmo um tanto mais lasso comparado ao que se dá nas outras palavras, como que procedendo a uma pequena pausa, incitando o leitor à reflexão, pela dicção amena advinda do intervalo de três sílabas átonas.

Quanto à medida dos versos, temos um decassílabo misto, um heptassílabo com acento na segunda, na quarta e na sétima sílabas e um eneassílabo acentuado na primeira, na quarta e na nona sílabas. E este verso, começado por uma tônica, seguida de dois ternários iniciais, que se somam a um binário final, explode numa sonoridade marcada por contratempos, evocando com essa dinâmica, própria da poesia modernista, a múltipla intencionalidade artística. Corre 
paralelo a tudo isso o fato de o poema não se distanciar de si mesmo, agregando ao que ele realiza o olhar atento para o processo de sua própria composição, jogando de forma equilibrada tanto no que se refere à estrutura rítmico-sonora quanto no que diz respeito ao tom poético interior.

\section{2 Entre a tradição e a ruptura}

$\mathrm{Na}$ estrutura notadamente paradoxal do poema "Verdade", sucedem-se momentos díspares cuja desmesura dos versos suscita uma atmosfera em que a configuração verbal se expande em seus próprios domínios, ampliando também o campo hipotético que resultará em uma aproximação homóloga e não em uma recorrência com relação ao fenômeno exterior.

A utilização de uma morfologia simples, aliada a uma sintaxe aparentemente linear como convém à narrativa, são apenas componentes da armadilha do texto. É comum ouvirmos afirmativas sobre Drummond nomeando, para efeito didático, os seus textos de "poema/prosa". Esse expediente de construção cria, a princípio, uma expectativa que se esmaece quando averiguamos mais detidamente cada etapa de seu processo construtivo. A estrutura do texto vista por dentro faz vir à tona, ao invés de um todo coeso e orgânico do ponto de vista semântico, um esvaziamento de informações que desencadeia numa precariedade das relações entre os elementos centrais do poema que se desagregam e, em lugar de se somarem entre si, multiplicam-se quanto às hipóteses da significação e, em vez de serem solidários, estes elementos se isolam; e a fábula exemplar, que parecia íntegra inicialmente, se desmorona, dando espaço a infindáveis interrogações. Nesse sentido, recorremos ao

Revista Texto Poético | ISSN: 1808-5385 | Vol. 18 (10 sem-2015) - p. 263 
professor Wolney Unes (1998) quando ele fala da leitura/tradução como "vontade de explicitar o mundo", que possui origens remotas e provoca sempre mais todos os leitores a mergulharem no desconhecido, na esperança de coletar aí alguma verdade, por menor que seja.

O texto em apreço perfaz-se, como organismo, por efeito de uma operação realizada em torno do signo verdade, seu mote central. E, neste jogo, este termo contrapõe-se a si mesmo numa relação de ordem tal que vai gerando, continuamente, significados ad infinitum. Várias hipóteses podem ser levantadas acerca de sua aplicação. A cada vez que ele aparece no texto, uma ou mais novas possibilidades se abrem. Todas elas, entretanto, apontam para sua incompletude, ao mesmo tempo que fala do inalcançável em poesia e, embora sua estrutura profunda apresente coerência interna, o que, em outros termos, viria a ser a configuração de sua lógica poética; sua estrutura externa se caracteriza pelo princípio da destituição do significado. E, se existe, em graus tênues, uma ligação filosófica entre as "verdades" nele proferidas, criando um universo mais ou menos coeso, não se pode dizer o mesmo no que diz respeito ao seu procedimento interno.

Tal expediente, considerando a conjunção dos pares agenteemissor / sujeito-receptor, como diria S. Zótkieviski, no diálogo pragmático da leitura, é uma característica recorrente da lírica modernista, uma vez que tal conduta estética reveste a palavra de uma energia capaz de colocá-la em patamares superiores aos da concepção do termo verdade em seu status meramente descritivo, relativizando e dialetizando de tal modo as suas nuances semânticas que possamos perceber, na prática, o efeito da intenção que visa unir 
o real ao possível, ao fantástico, ao intangível numa relação metafórica progressiva e interminável.

\section{3 Dos eixos analíticos}

É sob esta ótica que reiteramos, no poema dado, um olhar que evolui para o interpretativo, operando sobre três eixos. O primeiro deles concerne ao formato externo, centrado nos motivos morfossintáticos, momento em que observaremos os aspectos sonoros, no qual se notará o quanto, sintomática e intencionalmente, o discurso poético drummondiano se aproxima dos moldes cotidianos de linguagem, funcionando como procedimento atualizador do estilo. Nesta camada, a aparência discursiva do poema, lembra a retórica corrente, cuja vitalidade se dá mediante a oposição estabelecida entre termos diferentes. O segundo eixo é marcado pela ausência das oposições e, em seu lugar, ocorre uma tensão poética geradora de significâncias a partir das quais o vocábulo verdade se desdobra e se multiplica. Ocorre nessa camada do discurso poético de Drummond o que chamaremos de esvaziamento semântico, consolidando poeticamente a ideia de Anazildo Vasconcelos da Silva (1975), em seu livro Desconstrução/Construção no Texto Lírico dizendo-nos:

Hoje, o Espaço Externo manifesta uma total ausência de significação, mediante o esvaziamento da expressão objetiva. O mundo da técnica avança desmitificando as mais caras crenças do homem, despojando-o de suas mais firmes conviç̧ões. O homem se torna um ser desolado na face da terra, vivendo uma realidade que não o fundamenta nem o integra. (SILVA, 1975, p. 18) 
De fato, do ponto de vista semântico, o discurso poético do texto em pauta parece mesmo realizar essa profusão de significados que irá desembocar no terceiro momento que trataremos mais adiante, qual seja, o resultado de tal discurso, inclusive a sua função social, quando veremos que o esvaziamento do discurso revela também a figura vazia do homem moderno.

No esforço que aqui empreendemos para detectar essas marcas no poema de Drummond em questão, vemos, logo no primeiro verso, que o vocábulo verdade pode ser tomado como termo enunciador de generalidades, aproximando-se de sua aplicação comum, margeando a noção de verdade de que se lança mão aleatoriamente ao bel-prazer. Senão vejamos: "A porta da verdade estava aberta". O termo verdade, como signo central do verso, incrustado entre o substantivo "porta" e o adjetivo "aberta", aponta para o inequívoco propósito de desmistificar certas convenções que, muito embora sejam canonizadas pela tradição, tanto no âmbito da comunicação social quanto no da linguagem artístico-literária, não se sustentam quando aferidas com maior acuidade crítico-teórica.

Reportando-nos ao que sugere Machado de Assis, pela voz de seu narrador, no conto "Teoria do Medalhão", referindo-se à classe dos substantivos como "a realidade nua e crua" e ao adjetivo como "a alma do idioma", flagramos no texto drummondiano o substantivo verdade, na situação de adjunto adnominal de posse do substantivo porta, qualificado pela adjetivação simples da palavra aberta. Destarte, a adjetivação distorce, até certo ponto, o fluxo da lírica, desviando a função clássica do adjetivo de ativar o sentimento puro, evocando aqui uma espécie de razão intelectual que abrange mais que o mero sentimentalismo; envolvendo, assim, questões de inteligência e conhecimento, sem, necessariamente suscitar o 
entendimento e a emoção fortuita, predicativos dos quais a lírica moderna procura sempre se desvencilhar.

$\mathrm{Na}$ segunda vez em que o vocábulo verdade aparece no poema, ele se mostra recolhido, apresentando conotações múltiplas, dando claros sinais de um signo que agrega na sua totalidade uma imensa gama de significados, funcionando como significante de um vasto conjunto de objetos, coisas, ações e pensamentos dos mais variados gêneros. Ocorre uma multiplicação implícita e o termo se adequa em diversas unidades culturais, inserindo-se no reino da palavra-plural.

No verso "Assim não era possível atingir toda verdade", a ausência de um determinante precedendo a palavra verdade é sintomática, visto que se pode perceber nesta atitude de generalização a ampliação de suas possibilidades que lhe reveste de um vigor tal que fazem deste vocábulo um sinal multifacetado, afeito aos mais inusitados contextos.

A terceira vez que nos deparamos, neste poema, com a palavra verdade, já se pode notar a acentuação do esvaziamento semântico e o seu consequente afastamento dos pressupostos da linguagem ordinária, provocado pela fragmentação, posto estar ela aqui dividida em metades, com o significante multiplicando-se a cada vez que se aventa para um possível significado novo. As metades são conduzidas, cada uma delas, por uma "pessoa" igualmente dividida: "meia pessoa", que, por sua parte, traz apenas o perfil da verdade. Assim, vemos reduzir progressivamente a carga de significado das palavras, a par da sua perda de contato com o seu referente, abrindo deste modo um leque de discussão, tanto de ordem sintática quanto semântica.

Essa discussão nova que agora se instala em volta do signo verdade e se estende aos demais vocábulos que lhes servem de parelha é que pode dar conta da duplicidade da linguagem poética 
que, por um lado, não se aparta do mundo do homem com todos os seus conteúdos como presentificação deste, e, por outro, instaura a sua própria problematização, voltando-se para seus próprios domínios, revelando-se como "palavra aberta", geradora de significados que se desdobram em novos significantes numa escala infinita.

$\mathrm{Na}$ terceira estrofe, a palavra verdade aparece no poema pela quarta vez e aqui, dentro de um novo campo semântico, ao lado do verbo esplender, precedida do substantivo luminoso e seguida do substantivo focos, todos de uma mesma família. A atmosfera criada por estes termos pré-condiciona a leitura no sentido de nos conduzir a imaginar metaforicamente, já sem o menor lastro de qualquer referente, apontando para a anticomunicação, criando imagens cintilantes onde o vocábulo verdade evoca uma realidade que transcende ao simples entendimento, inserindo num mundo de virtualidades uma consciência que, tendo percorrido as etapas anteriores, percebe neste estágio uma ideia de totalidade, cuja substância se manifesta num conjunto isento de qualquer ordem, como verdadeira lógica poética; assemelhando-se ao que dizia Schiller sobre a linguagem poética que não tenciona aproximar-se da verdade, posto já sê-la em absoluto.

A noção de plenitude, em muitos sentidos, é uma destas convenções que neste poema são colocadas à prova. Assim como não há verdade absoluta em qualquer matéria, não há palavra plena. A justeza de uma palavra está na sua aplicação e não na sua semântica primordial. Este é um critério absolutamente circunstancial. O procedimento sintático de natureza horizontal, observado na construção do discurso formal e/ou cotidiano, é também questionado no poema em discussão. Em seu lugar, pode- 
se observar um conjunto de sentenças que apresentam inconteste fragilidade do ponto de vista coesivo, no momento em que se propõe a elas um olhar de natureza verticalizante.

É neste ponto que um texto aparentemente despretensioso requer uma outra leitura. Esta outra leitura não busca um sentido como fazemos na comunicação comum. A cada vez que a palavra verdade é proferida, mais afastada a percebemos de um suporte contextual e mais penetramos involuntariamente na lógica interna de um discurso que, do ponto de vista da linguagem cotidiana, representaria a mais absoluta perda de qualquer lógica.

Os vocábulos que contracenam, de perto, com o signo verdade neste poema, como porta e pessoa, além de outros, perdem seus contornos semânticos habituais, apresentando uma nova natureza: fugidia, deslizante, de sentido amplo, associada a uma considerável dose de imprecisão, promovendo uma sensação difusa, que suscita muito mais o prazer estético advindo da grandiosidade poética, que a compreensão.

O fato de "a porta da verdade" estar aberta, mas só deixar passar "meia pessoa de cada vez", promove um profundo arrefecimento das noções que cercam a palavra verdade, uma vez que, cotidianamente ela se apresenta como a última palavra, a ela se atribui um caráter de insofismável precisão. Entretanto, aqui, verdade é símbolo de passividade, ela "deixa passar" pela sua "porta", "meia pessoa", o que, por extensão subverte a distância habitual entre realidade e imaginação, colocando num patamar quase comum as noções de realidade e virtualidade que, por um prisma intelectualizado, se deixam entrever como legítimas sucedâneas uma da outra no jogo poético-literário. 
Cada frase deste poema pode ser concebida como um universo de significação independente, embora haja propositadamente a intenção do poeta de criar a ilusão de encadeamento a exemplo do que acontece ao nível da linguagem cotidiana, em que, pelo processo de concordância, o texto se revela em uma unidade indissolúvel. O sentido de unidade poética, entretanto, se dá de maneira diferente, como podemos observar neste texto. Ele se manifesta na sua literariedade, mais precisamente na sua unicidade, dentro de seu gênero, no seu modo particular de articular signos, na sua proposta única de feitura de um tecido que suscite o novo no sentido de propor abertura, como nos adverte Michael Rifaterre (1989).

Esta abertura consiste, portanto, no fato de que o texto não nos oferece nenhuma resposta e sim uma infinidade de possibilidades em que uma metáfora vai gerando outra e assim se dá sucessivamente, gerando por consequência a originalidade que não consiste em dizer algo único, mas de fazê-lo de seu jeito único.

Ainda considerando algumas das diversas racionalizações a que os vocábulos e expressões deste texto nos conduzem, percebemos dois grandes momentos neste poema. O primeiro, diz respeito à angústia humana que, ante a verdade fragmentada e incompleta, acaba nos impulsionando a violar o canal de inserção em seu universo, a sua porta.

Os verbos "arrebentar" e "derrubar", ambos sugestivos de ações deliberadamente demolidoras, são sintomas de uma atitude marcada pelo signo da intolerância de quem busca respostas confortáveis, definitivas, nesse caso, sobre poesia. No segundo momento, têm-se as consequências dos procedimentos adotados no primeiro. Aqui, a luminosidade da verdade é atingida, pode-se vislumbrar o seu brilho. Porém, persiste a sua divisão, e ambas as 
partes da verdade portam belezas iguais. E, em se tratando de conjecturas inerentes ao belo, há sempre o risco de opinarmos a partir do que se vê ou do que se pretende, em detrimento de um mergulho mais profundo nos domínios do objeto artístico que se nos apresenta.

Nesse estágio, encontra-se o terceiro momento de nossas perquirições acerca do poema em pauta, qual seja: a pragmática ou funcionamento do texto, na condição de objeto estético integralizado no somatório da estrutura com o significado, agora tomados conjuntamente, perfazendo uma nova estrutura. É aqui que muitas questões entram em jogo e trazem à luz problemas como: a poesia como objeto da própria linguagem poética, a questão da especificidade do discurso poético, a visão de signo complexo (o signo verdade e a impossibilidade de sua definição), a interação necessária e inevitável entre significante e significado, a visão de objeto real e a ficcionalização do mundo objetivo, bem como a perda dos limites entre real e imaginário, real e fantástico, real e virtual; ou, ainda, a configuração dos objetos e sensações humanos na transfiguração própria da linguagem poética, além de inúmeros outros questionamentos inerentes à esfera da estética literária e da existência humana.

A ironia drummondiana, sempre perspicaz, arremata o poema quando coloca a necessidade de escolha como grande imperativo do ser humano. "E carecia optar. E cada um optou, conforme seus caprichos, suas ilusões, sua miopia" (ANDRADE, 1992, pp. 1005/6). As três opções remetem à impossibilidade da completude tanto do homem quanto da palavra, ao mesmo tempo em que aponta para o desassossego do signo poético, cuja noção semântica primordial se esvai, quando perde o seu referente, substituída por 
uma profusão de possibilidades, paradoxalmente inteligíveis nas mais diversas situações possíveis, partindo sempre da lógica da metáfora poética. Lógica esta que caminha, por vocação própria de ofício, na contramão da lógica da linguagem usual.

\section{3 . Considerações Finais}

É sempre prudente lembrarmos que, ao final de todo exame acerca de um texto, seja ele poético, como foi este caso, seja ele narrativo ou mesmo de natureza não literária, deva prevalecer, invariavelmente, a convicção da inesgotabilidade das significações e da vitalidade desse texto.

Toda palavra lançada constitui-se num desafio interpretativo/tradutório. No caso do poema de "Verdade", em especial, o desafio se intensifica, uma vez que o seu termo central já é polêmico por natureza. O termo "verdade" é, certamente, uma escolha feliz que haverá de suscitar discussões infinitas e conclusões mínimas. Conforme vimos na primeira parte de nossas indagações, o vocábulo "verdade", aliado a outros termos como "porta", "aberta", "pessoa" e muitos outros, cria uma atmosfera paradoxal na qual convivem as noções de amplitude, abertura e as de limitações, fechamento. Se, por um lado, "A porta da verdade estava aberta” (DRUMMOND, 1992, p. 105), por outro, “... só deixava passar meia pessoa de cada vez.". A amplitude, nesse caso, está configurada nos vocábulos "porta" e "verdade" enquanto que, nos signos "meia" e "pessoa", afloram os limites da condição humana, principalmente no que concerne ao conhecimento.

Desse modo, persiste o princípio da incompletude, da intraduzibilidade, sejam elas da condição ôntica do indivíduo, ou mesmo da condição própria da palavra poética, ou ainda falta da 
integralidade de que ressente qualquer leitura; sendo da palavra ou de mundo. Assim como as visões da semiótica de Zótkiewski e os pressupostos da leitura/tradução dos demais teóricos foram a "porta" por nós escolhida para observarmos, de dentro, certos aspectos do poema de Drummond em pauta, haverá muitas outras "portas" que, em última análise, são métodos que nos conduzem ao interior desse e de outros textos, ressalvando-se, portanto, a consciência de que jamais se chegará à totalidade de um texto, independentemente do caminho utilizado.

\section{Referências}

ANDRADE, Carlos Drummond de. Obra Completa. Rio de Janeiro: Nova Aguilar, 1992.

EVEN-ZOHAR, Itamar. 1990 [1978]. The Position of Translated Literature within the Literary Polysystem. In: Polysystem Studies, Poetics Today 11.1: 45-51, 1990

LOTMAN, Iuri. A estrutura do texto artístico. Coimbra: Editorial Estampa, 1978.

RIFFATERRE, Michael. A produção do texto. São Paulo: Martins Fontes, 1989.

SILVA, Anazildo Vasconcelos da. Desconstrução/Construção no Texto Lírico. Rio de Janeiro: Francisco Alves, 1975.

ZÓTKIEWSKI, S. Crítica. Trad. Maria Évora Águas. Enciclopédia Ernandi, vol. 17, Porto, Casa da Moeda, 1989. (Coleção Literatura - Texto) UNES, Wolney. Entre músicos e tradutores: a figura do intérprete. Goiânia: Editora da UFG, 1998. (Coleção Quíron, Série Ars n. 1) 